\title{
A New Acid Test for Ecological Restoration
}

It was twenty years ago this year that the University of WisconsinMadison Arboretum published, under the editorship and guiding spirit of Bill Jordan, the first issue of Restoration $\mathbb{E}$ Management Notes. The first issue of REMN focused on restoration activities in the midwestern United States with one large exception, a review by Robert P. McIntosh of a newly-published book titled, The Restoration of Land: The Ecology and Reclamation of Derelict and Degraded Land by A.D. Bradshaw and M.J. Chadwick. McIntosh wrote in his review, "British botanists and ecologists, including the authors of this book, have been active in combining the theory and practice of ecology and land management in achieving effective land restoration.... The authors have avoided polemic and emphasized the practical, let's-get-on-with-the-job approach to restoration." A few years later, in 1984, Tony Bradshaw was in Madison as part of the symposium that spawned Restoration Ecology: A Synthetic Approach to Ecological Research (Jordan and others 1987) and at which time he coined the well-known phrase, "Land restoration is the acid test of our ecological understanding."

At last year's Society for Ecological Restoration Conference in Liverpool, England, I had the good fortune to interview Tony Bradshaw along with several other people about state of ecological restoration in Europe. I would like to relate here some of what I learned because I think restorationists from United States, including myself, often fail to grasp the kind of important theoretical and practical work that is taking place in Europe, and the opportunities for helping people there restore or at least reclaim places in Europe, especially those truly degraded lands in eastern Europe left in the wake of the old Soviet economy.

After speaking with Tony, Irene Klever (from the Netherlands, but now teaching at the University of North Texas), Jim Harris (University of London), Rudy van Diggelen (University of Groningen, the Netherlands), Chris DeCleer (Flanders), and Ian Rotherham (Sheffield Halman University), it was easy to see that the European restoration scene is different from the North American or Australian - but more because of land use history, politics, and social values than the restoration technology or ecological theory. Speaking with the experience of 20 years behind him, Tony Bradshaw told me in between sips of his favorite ale, "I used to think there was a considerable difference between American and British approaches to restoration. Now I don't think there is. Things are coming together. I don't see any fundamental differences."
In terms of politics, every person mentioned the importance of the European Union's agricultural policy, which has focused production in eastern Europe, made farming in western European countries less profitable, and caused government in the west to adopt policies of acquiring former or unprofitable farmland for conservation purposes. Chris DeCleer called the EU's agriculture policy "the driving force" behind conservation and restoration opportunities. Irene Kleever told me about Netherland's New Nature Program, which was developed as a response to the EU ag policy, and Bradshaw mentioned how the Wildlife Trust in England is buying cheap, degraded farm land for nature conservation. Kleever also compared her experiences in both the Netherlands and the United States, and strongly suggested that the policies of New Nature in Holland are much more geared to engaging public participation than community-based projects in the United States. Fellow countryman, Rudy van Diggelen, explained that in a small country such as the Netherlands, the public is never far from the work being proposed and, therefore, their participation and approval are key issues in obtaining support for restoration projects. But, he told me, "Restoration will play an important role in the next few decades. One of the reasons is that it is widely accepted by our mainly urban public as a worthwhile value."

But countries within Europe have very distinct environmental agendas and different histories of land use. Ian Rotherman noted that "Nature conservation is very much linked to politics here. There is a big difference in terms of the problems and the willingness to solve them between the northwestern countries of Europe and those in the Mediterranean and eastern Europe." Chris DeCleer was even more blunt: "I think that the Netherlands and the United Kingdom are really at the forefront of ecological restoration in Europe. In Flanders public awareness is very low, we are a minority. We have to take a lot of risks, but the situation is improving slightly. Belgium is worse than Flanders, and the French think they have so much Nature that they don't have to do anything about it." Both van Diggelen and Bradshaw agreed that there was little going on in France, but Bradshaw quickly pointed to eastern Europe as a hotbed of activity-a new frontier for restoring the land. "In eastern Europe there is extensive damage from mining that is only now beginning to be dealt with. They're drawing on the expertise of the West, but they're taking a more relaxed approach as to the actual target community." Jim Harris, who has been doing a fair amount 
of work in eastern Europe, agrees with Bradshaw, "There are some excellent experiments going on to determine how to deal with the extreme situations caused by unregulated mining. We have to look at what we can put back that would be valuable in terms of biodiversity and biological services, and we have to think of these projects in terms of the local populations and their needs."

In terms of restoration strategy in Europe, I did note a detectable, if subtle, rift between Bradshaw and some younger restorationists over the issue of active versus passive restoration. Tony believes in what he calls a "relaxed" approach-being patient, not worrying about total control, and letting Nature do as much as possible. Others, like van Diggelen, disagree: "The older generation does not support active restoration. They reconfigure the landscape or hydrology and then let species come in as they will. This is considered the 'natural' way."

Regardless of their approach, everyone agreed there is plenty of restoration needed in Europe and that, in many cases, people are supportive. But restorationists in Europe remain relatively few in number compared to their North American counterparts. Furthermore, as Harris pointed out to me, they are at a bit of disadvantage because of differences in language and culture, especially when it comes to sharing information. Nevertheless, Harris and others are working diligently to create a chapter of the Society for Ecological Restoration in Europe as a means of supporting one another and their work.

As we sat in the hotel pub while the conference for which he was one of the principle organizers was drawing to a close, Tony
Bradshaw reminded me, "The Society for Ecological Restoration should not think of itself as something that applies only to North America because the principles and ideas of ecological restoration are universal. It behooves restorationists on both sides of the Atlantic to look at what each other are doing."

Is Bradshaw suggesting another acid test, one of a personal and organizational type? I think so, and urge restorationists everywhere to meet the challenge. Readers of this journal will begin to see more articles and notes from Europe and other parts of the world. Anyone especially interested in restoration ecology in Europe can find out more by making plans to attend the 3rd European Conference on Restoration Ecology, which will be held in Budapest from August 25-31, 2002.

\section{몸}

The tragic events of September 11, 2001 have brought all of us face-to-face with the fact that we are becoming gradually, and at times painfully, a global community. The staff of Ecological Restoration sends our sincere regards to our friends and colleagues in New York and Washington, D.C. as they work through the meaning of the tragedy they witnessed firsthand. Please know that restorationists everywhere are with you as we, too, try to imagine a global world of peace, environmental justice, and sustainable cultural and biological diversity.

Dave Egan 